Malaysian Journal of Social Sciences and Humanities (MJSSH)

Volume 4, Issue 7, November 2019

e-ISSN : 2504-8562

Journal home page:

www.msocialsciences.com

\title{
Membangun Peradaban Islam Menurut Al-Qur'an: Penelitian Surah Al-Kahfi
}

\author{
Siti Nur Aisyah Mohd Azemi Azman ${ }^{1}$, Sarinah Yahya ${ }^{1}$ \\ 1Fakulti Usuluddin, Universiti Islam Sultan Sharif Ali, Brunei Darussalam \\ Correspondence: Siti Nur Aisyah Mohd Azemi Azman (18MC201@siswa.unissa.edu.bn)
}

\begin{abstract}
Abstrak
Setiap bangsa di dunia ini mempunyai istilah sendiri untuk memberi gambaran mengenai tahap kegemilangan peradaban dan kemajuan hidup yang dicapai oleh mereka. Secara umumnya, peradaban adalah hasil dari rangkaian produk budaya manusia. Semakin banyak produk budaya satu bangsa, semakin tinggi pula tingkat peradaban bangsa tersebut. Untuk membangun sesebuah peradaban, agama juga menjadi salah satu peranan yang penting kerana peranan agama membentuk pandangan semesta seseorang dan sesebuah masyarakat serta perilaku dan tindakan mereka dalam kehidupan. Oleh kerana itu, tujuan kajian ini adalah ingin membuktikan bahwa agama Islam adalah agama yang universal dan menyeluruh, dan ianya jelas dengan intipati yang ada dalam al-Qur'an yang menyentuh seluruh aspek kehidupan baik di dunia mahupun di akhirat kelak. Bahkan juga banyak ayat-ayat al-Qur'an yang menyentuh tentang peradaban manusiawi. Salah satu contohnya adalah surah al-Kahfi, di dalamnya terdapat banyak kisah yang diceritakan untuk kita mengambil ibrah dari kisah-kisah tersebut. Antara kisah yang terdapat di dalam surah al-Kahfi adalah kisah Zulqarnain seorang hamba Allah SWT yang sangat tawadhuk dalam mengelola kerajaannya, sehingga kisahnya telah diceritakan oleh Allah SWT di dalam al-Qur'an. Juga terdapat beberapa kisah lain yang dapat dikaitkan dalam pembinaan sahsiah diri dan masyarakat, kerana dalam membangun peradaban Islam menurut al-Qur'an tidak hanya mengutamakan dari sudut material semata tetapi ianya juga harus berjalan seiring dengan sudut spiritual. Kajian ini menggunakan pendekatan kualitatif melalui metode analisis yang berkaitan seperti buku dan kitab tafsir, artikel serta kertas kerja. Hasil dari kajian ini membuktikan bahawa al-Qur'an merupakan sumber asas dalam membangun peradaban Islam dan menunjukkan bahawa terdapat tiga elemen penting untuk membangun peradaban Islam iaitu, aqidah, syariat dan akhlak.
\end{abstract}

Kata kunci: pembangunan peradaban Islam, Surah Al-Kahfi, kisah Zulqarnain, Ibrah Al-Qur'an

\section{Building Islamic Civilization According to the Quran: Research on Surah Al-Kahfi}

\begin{abstract}
Every nation in the world has its own terminology to describe the glory levels of civilization and the progress they have made in life. Generally speaking, civilization is the result of different human culture. The more cultural products of a nation, the higher the level of civilization of the nation. In order to build a civilization, religion is also one of the important role because it form the worldview of a person and society as well as their behaviour and actions in life. Therefore, the purpose of this study is to prove that Islam is a religion of universal and comprehensive, and it is clear from the essence of Qur'an that touches all aspects of life in this world and in the hereafter. There are also a lot of Qur'anic verses that touch on human civilization. One of the example is surah Al - Kahfi, which consist of a lot of stories for us to take lessons from it. Among the stories found in surah Al - Kahfi is the story of
\end{abstract}


Zulqarnain a servant of Allah SWT which is very modest in managing the kingdom, to the extent of Allah SWT mentioning him in the Qur'an. There are also other stories that can be linked to the spiritual self development and society because in developing an Islamic civilization according to the Quran, it does not only prioritize in terms of material point of view alone but it also have to be in line with the spiritual aspect. This study uses a qualitative approach through relevant analysis methods such as books and kitab tafsir, articles and paper. The results of this study prove that the Qur'an is a fundamental source in the development of Islamic civilization and shows that there are three essential elements of Islamic civilization namely aqidah, shari'a and akhlak (morals).

Keywords: building Islamic civilization, Surah Al-Kahfi, kisah Zulqarnain, Ibrah Al-Qur'an

\section{Pengenalan}

Agama Islam yang dibawa oleh Nabi Muhammad SAW telah berjaya membentuk sebuah peradaban yang tinggi yang dikenali dengan peradaban Islam. Dengan ajaran yang datang daripada Allah SWT, Islam mampu melahirkan pengikut yang berperadaban tinggi dan berakhlak mulia. Peradaban Islam ialah suatu peradaban kemanusiaan bersifat universal meliputi seluruh daerah dan seluruh bangsa yang berada di bumi ini yang terdiri dari orang-orang yang percaya kepada Allah, percaya kepada malaikat, kitab al-Qur'an, rasul dan percaya kepada hari akhirat. Peradaban Islam berbeza dengan peradaban dunia yang lain kerana ia meletakkan al-Din (agama) sebagai asas yang membentuk peradaban, bukan manusia yang membentuknya. Al-Qur'an menjadi sumber utama atau sumber asas dalam membangun peradaban Islam, kerana ia mengandungi segala nilai, dasar, prinsip serta hukum untuk membimbing manusia bagi mencapai perhubungan dan kesempurnaan hidup. Ia juga merangkumi konsep ketuhanan, pengetahuan tentang perkara ghaib, asas perundangan, moral, fakta-fakta sains, sejarah manusia dan lain-lain lagi.

\section{Definisi Peradaban Islam}

Dalam bahasa arab, terdapat beberapa istilah yang digunakan oleh para ilmuan Islam untuk memberi makna peradaban. Antara tokoh ilmuan Islam seperti Muhammad 'Abduh yang menggunakan istilah al-madaniyyah yang berasal daripada perkataan madana, madani, madinah yang membawa pengertian pembinaan kota dan tempat tinggal menetap (Nik Mohd, 2009). Dari perkataan ini juga ada yang menggunakan istilah tamaddun yang memberi makna yang sama yaitu kota. Tamadun merupakan istilah yang banyak digunakan dalam masyarakat melayu untuk menceritakan tentang peradaban.

Selain itu, Ibnu Khaldun menggunakan istilah 'umran dalam bukunya al-Muqaddimah. Istilah ini berasal daripada perkataan 'amara yang membawa maksud kawasan tanah dan rumah yang didiami, diduduki orang, tinggal menetap dalam keadaan berkembang subur dan makmur (Nik Mohd, 2009).

Ada juga yang menggunakan istilah al-hadharah seperti Malik bin Nabi, beliau mengatakan bahawa ia berasal daripada perkataan hadhar yang membawa maksud kehidupan secara menetap, tempat lahirnya perkembangan ilmu, kesenian, kesusasteraan undang-undang dan kemasyarakatan, serta mencapai tahap kehidupan yang tinggi, bukan liar dan ganas (Nik Mohd, 2009). Menurut M. Abdul Jabar Beg dalam bukunya Perspectives of Civilization, orang-orang Arab sekarang pada umumnya menggunakan kata hadharah sebagai istilah untuk peradaban (M. Abdul, 1985).

Walaupun terdapat pelbagai istilah bagi maksud peradaban, berdasarkan huraian di atas dapat disimpulkan secara umum bahawa yang dimaksudkan dengan peradaban adalah suatu kemajuan yang dicapai oleh manusia yang berpusat di bandar atau kota.

Namun apabila dikaitkan peradaban dengan Islam, atau disebut dengan peradaban Islam maka ianya membawa maksud lain yang lebih khusus. Salah seorang tokoh Islam yang telah membahas tentang peradaban Islam adalah Abu al-A'la al-Maududi. Beliau berpendapat bahawa peradaban Islam itu 
bermula apabila manusia memahami tugas mereka sebagai khalifah Allah SWT di muka bumi ini, kemudian melaksanakan tujuan hidup berdasarkan keyakinan dan pemikiran asasi (iman) beserta dengan pendidikan atau pengetahuan yang jelas bersama dengan kumpulan manusia yang bermasyarakat (Abul A'la Al-Maududi, 1985).

Ibnu Khaldun pula berpendapat bahawa Allah SWT menjadikan manusia dan memberi mereka hidayah serta menjadikan mereka memiliki fitrah mencari kehidupan dan mempertahankan diri dari bahaya. Mempertahankan diri itu memerlukan bantuan masyarakat. Oleh itu mereka saling bantu-membantu antara satu sama lain hinggalah sempurna keadaan mereka sebagai khalifah Allah SWT di muka bumi (Ibnu Khaldun, 1986).

Manakala Muhamad 'Uthman El Muhammay mengatakan bahawa peradaban Islam ialah peradaban yang dibenarkan atas dasar ajaran ketuhanan (Abd Aziz, 2000). Ini kerana agama Islam adalah berbeza dengan agama yang lain. Islam adalah satu-satunya risalah yang memberikan manusia satu prinsip yang mempunyai ciri seimbang dan lengkap. Menurut Yusuf al-Qardhawi yang dimaksudkan dengan seimbang di sini adalah ciri pertengahan di antara sifat keterlaluan dan sikap tidak ambil berat (Yusuf Al-Qardhawi, 1999). Ciri ini menunjukkan bahawa agama Islam adalah sempurna, kerana dalam kehidupan ini Islam bukan hanya mewajibkan manusia untuk memohon kebaikan di akhirat, tetapi kita digalakkan juga untuk memohon kebaikan di dunia. Firman Allah SWT dalam surah al-Baqarah ayat 201:

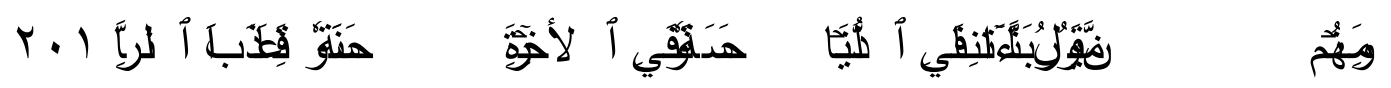

Maksudnya: "Dan di antara mereka ada orang yang berdoa: "Ya Tuhan kami, berilah kami kebaikan di dunia dan kebaikan di akhirat dan peliharalah kami dari siksa neraka."

Dalam al-Qur'an jelas mengatakan bahawa Allah SWT telah mencipta manusia untuk dijadikan khalifah di muka bumi ini. Firman Allah SWT dalam surah al-Baqarah ayat 30:

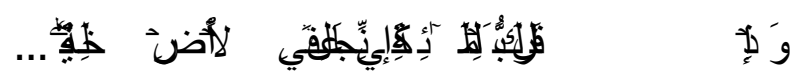

Maksudnya: "Ingatlah ketika Tuhanmu berfirman kepada para Malaikat: "Sesungguhnya Aku hendak menjadikan seorang khalifah di muka bumi..."

Manusia juga telah diciptakan Allah SWT sebagai pemakmur di bumi ini. Firman Allah SWT dalam surah Hud ayat 61:
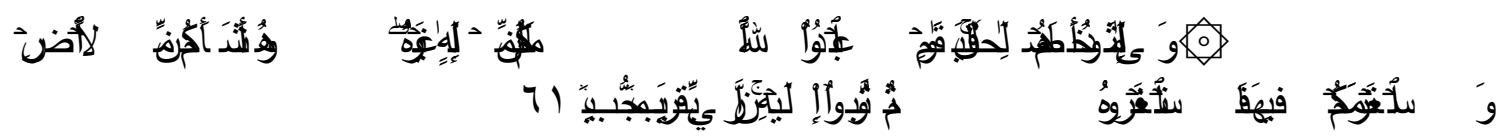

Maksudnya: "Dan kepada Tsamud (Kami utus) saudara mereka Shaleh. Shaleh berkata: "Hai kaumku, sembahlah Allah, sekali-kali tidak ada bagimu Tuhan selain Dia. Dia telah menciptakan kamu dari bumi (tanah) dan menjadikan kamu pemakmurnya, karena itu mohonlah ampunan-Nya, kemudian bertobatlah kepada-Nya, Sesungguhnya Tuhanku amat dekat (rahmat-Nya) lagi memperkenankan (doa hamba-Nya)".

Menurut Abu al-A'la al-Maududi, seorang muslim yang menyedari tanggungjawab sebagai khalifah seharusnya bekerja dengan giat dan penuh semangat dalam mempergunakan dan memanfaatkan segala apa yang terdapat di dunia ini, tetapi ianya tidak boleh melampaui batas dan terkeluar dari apa yang telah digariskan oleh Islam (Abul A'la Al-Maududi).

Peradaban Islam tidak sama dengan peradaban lain contohnya peradaban barat yang menjadikan materialisme sebagai agama dan pragmatisme sebagai jalan hidup mereka. Ini seperti yang dikatakan oleh seorang tokoh ilmuan Eropah Leopold Weis yang berbangsa Austria yang kemudiannya memeluk Islam dan menggantikan namanya menjadi Muhammad Asad. 
Dalam bukunya beliau menulis bahawa halatuju agama sentiasa berasaskan kepada keyakinan bahawa di sana ada suatu sistem hukum dan tatacara adab yang bersifat mutlak lagi menyeluruh bahawa kita sebagai manusia terpaksa tunduk kepada ketentuannya. Tetapi kemajuan barat moden tidak memperkirakan langsung keperluan tunduk kepada sesuatu kecuali mereka hanya tunduk kepada kepentingan ekonomi, sosial ataupun kebangsaan. Sembahan mereka yang sebenarnya bukan dari jenis yang spiritual, yang disembah adalah kemewahan (Muhammad Asad, 1981).

Kesimpulannya peradaban Islam tidak seperti peradaban lain yang hanya mementingkan sudut material semata, tetapi ianya juga harus berjalan seiring dengan sudut spiritual. Maka dapat difahami bahawa peradaban Islam membawa erti kemajuan yang dicapai oleh masyarakat muslim sama ada dalam bidang kerohanian atau kebendaan dengan berpandukan kepada sumber ajaran Islam bagi memenuhi amanah Allah SWT kepada manusia sebagai khalifah Allah SWT di muka bumi demi kebahagiaan mereka di dunia dan akhirat.

\section{AL-QUR'AN SEBAGAI SUMBER ASAS PERADABAN ISLAM}

Apabila menyentuh soal peradaban, kita tidak dapat lari dari perbincangan mengenai sejarah. Dengan sejarah kita dapat mengetahui tentang sesebuah peradaban tersebut, begitu juga dengan perdaban Islam.

Salah satu keistimewaan al-Qur'an yang terdapat di dalamnya adalah al-Qur'an telah mengungkap banyak perkara sejarah dan berita ghaib seperti kejadian masa lampau, juga peristiwa masa akan datang atau masa kini yang belum diketahui manusia (Ab Latif, 2014).

Al-Qur'an telah memperlihatkan beberapa ciri penting tentang sejarah dan hubungannya dengan peradaban manusia melalui peristiwa-peristiwa dan beberapa contoh umat manusia yang terdahulu. ia bermula dengan kisah para Nabi 'alaihissalam, kemudian kisah kaum seperti 'Ad, Thamud, Luth, Fir'aun hinggalah kepada kerajaan Saba' dan sebagainya.

Berdasarkan peristiwa-peristiwa tersebut, al-Quran telah menyifatkan beberapa peradaban sebagai melampau dan membawa kerosakan kerana ia berdiri di atas asas dan perlambangan materialisme. Mereka membangunkan bumi tetapi merosak manusianya, mereka mendirikan bangunan-bangunan tetapi menghancurkan nilai, mereka bekerja untuk dunia tetapi melupakan akhirat, mereka memakan nikmat Allah SWT tetapi tidak melaksanakan syukur, mereka zalim kepada yang lemah, mengabaikan ibadat dan tunduk mengikut syahwat (Yusuf Al-Qardhawi).

Oleh sebab itu Allah SWT telah menurunkan azab dan seksa bagi mereka dan mereka dimusnahkan. Sekaligus ia menjadi peringatan bagi yang zalim dari kalangan generasi kemudian, jika mereka tidak mengambil pelajaran dari apa yang menimpa pada mereka ini ataupun sekiranya mereka tidak melakukan taubat dan pembaikan bagi segala kesilapan.

Firman Allah SWT dalam surah al-Qasas ayat 58:
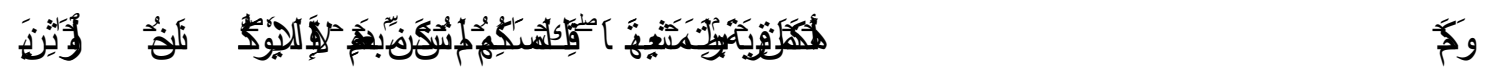

Maksudnya: "Dan berapa banyaknya (penduduk) negeri yang telah Kami binasakan, yang sudah bersenang-senang dalam kehidupannya; maka itulah tempat kediaman mereka yang tiada di diami (lagi) sesudah mereka, kecuali sebahagian kecil. Dan Kami adalah Pewaris(nya)".

Kita dapat lihat bahawa dalam peradaban Islam, al-Qur'an telah berfungsi untuk menentukan sesuatu kemajuan itu sama ada selaras dengan Islam atau tidak. Al-Qur'an berperanan membezakan antara sistem Islam dengan sistem yang tidak Islam. Dalam bidang-bidang politik, perundangan, kehakiman, pentadbiran, ekonomi, perniagaan, kekeluargaan, perkahwinan, kemasyarakatan, kesenian, perubatan dan lain-lain hendaklah berpandukan kepada al-Qur'an (Abd Aziz Harjin)

Firman Allah SWT dalam surah an-Nisa' ayat 59: 


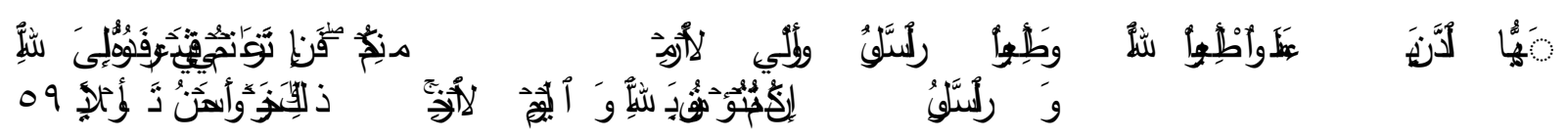

Maksudnya: "Hai orang-orang yang beriman, taatilah Allah dan taatilah Rasul (Nya), dan ulil amri di antara kamu. Kemudian jika kamu berlainan pendapat tentang sesuatu, maka kembalikanlah ia kepada Allah (al-Qur'an) dan Rasul (sunnahnya), jika kamu benar-benar beriman kepada Allah dan hari kemudian. Yang demikian itu lebih utama (bagimu) dan lebih baik akibatnya".

Ayat di atas menjelaskan bahawa sewajarnya seorang yang beriman itu lebih mengutamakan peraturan Allah SWT dalam kehidupan mereka iaitu dengan berpandukan kepada al-Qur'an dan al-Sunnah Rasul SAW. Tidak sepatutnya mereka mengikut hawa nafsu tanpa merujuk kepada hukum Allah SWT dalam menjalani kehidupan ini.

\section{PENGENALAN SURAH AL-KAHFI DAN KISAH ZULQARNAIN}

Surah al-Kahfi adalah surah yang ke 18 menurut susunan mushaf, mempunyai 110 ayat dan merupakan salah satu daripada surah Makkiyyah iaitu surah yang diturunkan selepas hijrah. Al-Kahfi di dalam bahasa melayu bermakna gua. Ayat-ayatnya mengandungi dasar-dasar akidah dan iman (Abdul Hadi Awang, 2013).

Surah ini juga terdapat banyak fadhilat jika kita mengamalkannya, antaranya seperti yang terdapat dalam sebuah hadis Imam Ahmad meriwayatkan dari Abu ad-Darda', dari Nabi SAW beliau bersabda:

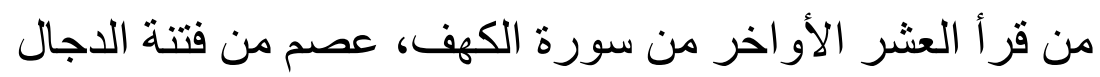

Maksudnya: "Barangsiapa yang membaca sepuluh ayat terakhir dari surah al-Kahfi, maka ia akan dilindungi dari fitnah Dajjal." (HR. Muslim dan an-Nasai’) (Uthman, 2010).

Surah al-Kahfi adalah salah satu surah yang terkenal dengan surah yang mempunyai banyak cerita atau kisah-kisah yang terdapat di dalam al-Qur'an. Menurut Sayyid Quthb dalam kitabnya "Tafsir Fi Zhilalil Qur'an', kisah-kisah merupakan unsur yang dominan di dalam surah al-Kahfi (Sayyid Quthb, 2003).

Antara kisah popular yang terdapat didalam surah ini adalah kisah Zulqarnain, iaitu seorang raja yang diberi keagungan dan kebesaran oleh Allah SWT (Abdul Hadi Awang). Beliau merupakan raja Islam yang beriman kepada Allah SWT dan menegakkan keadilan di atas muka bumi ini. Beliau juga menggunakan kekuasaan yang ada padanya bukan untuk diri sendiri tetapi untuk rakyat dan manusia seluruhnya.

Firman Allah SWT:
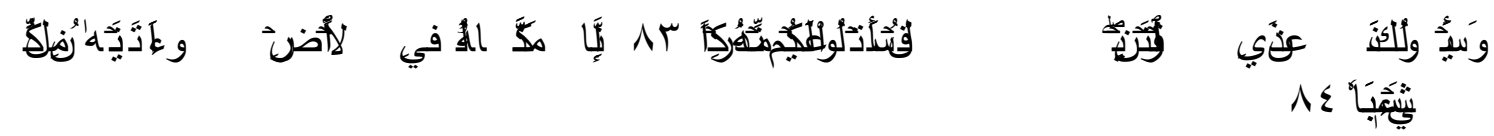

Maksudnya: "Mereka akan bertanya kepadamu (Muhammad) tentang Zulqarnain. Katakanlah: "Aku akan bacakan kepadamu cerita tentangnya. Sesungguhnya Kami telah memberi kekuasaan kepadanya di (muka) bumi, dan Kami telah memberikan kepadanya jalan (untuk mencapai) segala sesuatu". [Surah Al-Kahfi: 83-84]

Ramai ahli sejarah yang mempunyai pendapat yang berbeza apabila menyentuh soal siapakah Zulqarnain yang dimaksudkan oleh Allah SWT. Tetapi al-Qurthubi berpendapat bahawa sebagai seorang mukmin cukuplah sekadar kita mengimani, percaya dan yakin serta mengambil ibrah dari kisah yang telah diceritakan dalam al-Qur'an. Adapun Zulqarnain yang disebut di dalam ayat ini ialah 
seorang lelaki beriman yang saleh (Al-Qurthubi, 2008) dan menjadi seorang raja beriman kepada Allah SWT dan menegakkan hukum-hukumNya (Abdul Hadi Awang).

Menurut Ibnu Kathir yang dimaksudkan dengan kekuasaan di dalam ayat tersebut adalah seperti kekuasaan yang ada selayaknya bagi seorang raja seperti bala tentera, peralatan perang dan beberapa benteng. Oleh sebab itu, ia dapat menguasai bumi dari timur ke barat sehingga semua yang ada pada masa itu tunduk kepadanya. Tambah Ibnu Kathir lagi bahawa Allah SWT juga telah mengurniakan ilmu pengetahuan kepada Zulqarnain (Abdullah, 2008).

Ayat seterusnya mengisahkan perjalanan Zulqarnain dari suatu tempat ke suatu tempat yang lain. Firman Allah SWT:

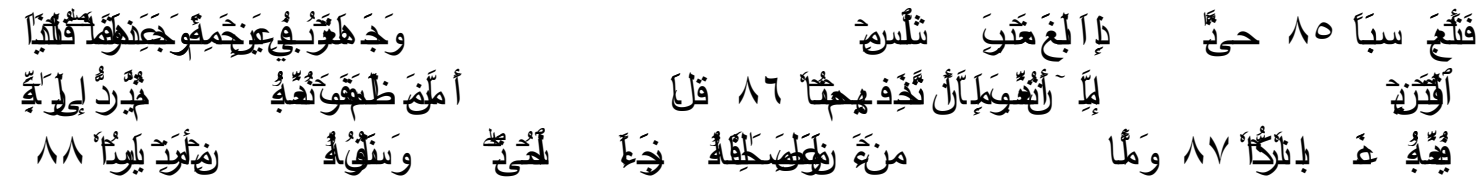

Maksudnya: "maka dia pun menempuh suatu jalan. Hingga apabila dia telah sampai ketempat terbenam matahari, dia melihat matahari terbenam di dalam laut yang berlumpur hitam, dan dia mendapati di situ segolongan umat. Kami berkata: "Hai Zulqarnain, kamu boleh menyiksa atau boleh berbuat kebaikan terhadap mereka. Berkata Zulqarnain: "Adapun orang yang aniaya, maka kami kelak akan mengazabnya, kemudian dia kembalikan kepada Tuhannya, lalu Tuhan mengazabnya dengan azab yang tidak ada taranya. Adapun orang-orang yang beriman dan beramal saleh, maka baginya pahala yang terbaik sebagai balasan, dan akan kami titahkan kepadanya (perintah) yang mudah dari perintahperintah kami." [Surah Al-Kahfi: 85-88]

Ketika berhadapan dengan kaum tersebut, Allah SWT memberi dua pilihan kepada Zulqarnain, sama ada mahu mengazabkan mereka dengan cara membunuh atau berlaku baik terhadap mereka dengan cara menyampaikan dakwah agar mereka beriman kepada Allah SWT. Menurut Ibnu Kathir perkataan zalim dalam ayat ini menunjukkan kekafiran dan kemusyrikan kepada Allah SWT (Abdullah, 2008).

Dalam ayat ini menunjukkan Zulqarnain menyerahkan urusan mengazabkan orang-orang yang zalim kepada Allah SWT. Ini menunjukkan bahawa betapa Zulqarnain itu beriman dan percaya kepada Allah SWT, walaupun dia seorang raja yang paling berkuasa dan kuat pada masa itu. Bagi orang-orang yang beriman pula, Zulqarnain mengatakan bahawa mereka akan mendapat ganjaran pahala dari sisi Allah SWT. Dia tidak menjanjikan sebarang upah atau ganjaran di dunia yang bersifat sementara ini.

Allah SWT telah memberi kebebasan dan kemampuan kepada Zulqarnain untuk bertindak mengikut apa yang dikehendakinya. Namun begitu, dia tidak bertindak secara sewenang-wenangnya dan melulu tetapi bertindak dengan cara yang adil (Abdul Hadi Awang).

Allah SWT berfirman dengan ayat-ayat yang seterusnya menjelaskan bahawa Zulqarnain meneruskan pengembaraannya dan ia menempuh jalan dari tempat terbenamnya matahari menuju ke tempat terbitnya. Setiap kali melewati segolongan umat, ia dapat mengalahkan dan menguasai mereka serta menyeru mereka kepada Allah SWT. Sehinggalah Zulqarnain bertemu dengan suatu kaum yang tidak mempunyai bangunan yang dapat dijadikan sebagai tempat tinggal mereka, tidak juga pepohonan yang dapat menaungi mereka dan menghalangi mereka dari terik matahari (Abdullah Bin Muhammad).

Seterusnya beliau melanjutkan perjalanannya sehinggalah bertemu dengan kaum yang tidak dapat difahami bahasa mereka. Mereka telah meminta bantuan Zulqarnain untuk menyelamatkan mereka dari kejahatan dan kezaliman yang dilakukan oleh Yakjuj dan Makjuj. Mereka juga sanggup membayar kepada Zulqarnain atas bantuan tersebut. Tetapi Zulqarnain menolaknya dengan penuh berakhlak iaitu dengan mengembalikan segala kekayaan yang telah diperoleh dari Allah SWT adalah lebih baik daripada apa yang mereka ingin berikan, dan beliau hanya meminta mereka untuk sama-sama membangun benteng tersebut. Ianya dirakamkan dalam firman Allah SWT: 


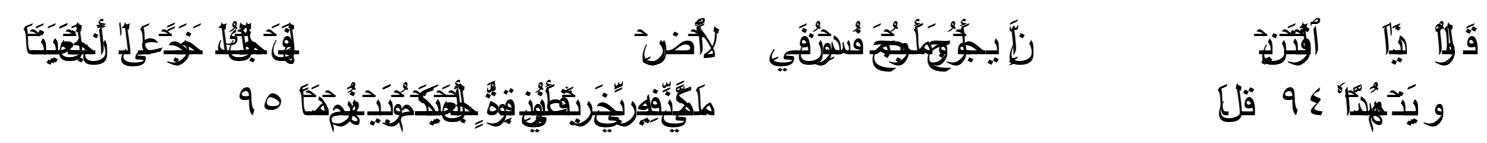

Maksudnya: "Mereka berkata: "Hai Zulqarnain, sesungguhnya Yakjuj dan Makjuj itu orang-orang yang membuat kerusakan di muka bumi, maka dapatkah kami memberikan sesuatu pembayaran kepadamu, supaya kamu membuat dinding antara kami dan mereka? Zulqarnain berkata: "Apa yang telah dikuasakan oleh Tuhanku kepadaku terhadapnya adalah lebih baik, maka tolonglah aku dengan kekuatan (manusia dan alat-alat), agar aku membuatkan dinding antara kamu dan mereka." [Surah AlKahfi: 94-95]

Akhirnya benteng tersebut telah dibangunkan oleh Zulqarnain dengan bantuan kaum yang telah meminta bantuan itu, sehingga golongan Yakjuj dan Makjuj tidak dapat lagi melakukan kejahatan dan kezaliman terhadap mereka. Zulqarnain sekali lagi menunjukkan sikap seorang pemerintah yang berakhlak, bermoral dan bertaqwa kepada Allah SWT kerana telah menyandarkan segala perbuatan yang dilaksanakannya kepada Allah SWT. Beliau tidak berbangga dan bermegah dengan kekuasaan dan kemampuan yang dikurniakan oleh Allah SWT kepadanya, seperti dalam firman Allah SWT beliau berkata:

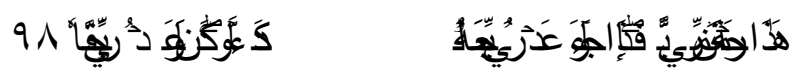

Maksudnya: "Zulqarnain berkata: "Ini (dinding) adalah rahmat dari Tuhanku, maka apabila sudah datang janji Tuhanku, Dia akan menjadikannya hancur luluh; dan janji Tuhanku itu adalah benar." [Surah Al-Kahfi: 98]

Berdasarkan kisah Zulqarnain yang telah diterangkan, dapat kita simpulkan bagaimana seorang pemimpin yang telah menjalankan tugas dan tanggungjawab sebagai seorang raja yang beriman kepada Allah SWT. Ini menunjukkan betapa kuatnya pegangan aqidah islaminya dalam menjalani kehidupan di dunia. Zulqarnain juga telah memerintah dengan adil, menjalankan undang-undang Allah SWT dan juga menyampaikan risalah Islam ke serata tempat, menunjukkan bahawa beliau melakukan sesuatu perkara berlandaskan syariat Islam. Akhirnya dapat kita lihat bagaimana sikap Zulqarnain dalam berinteraksi dengan setiap kaum dan mengembalikan apa yang selayaknya kepada Allah SWT, menunjukkan akhlak islami nya.

\section{MEMBANGUN PERADABAN ISLAM DARI KISAH ZULQARNAIN}

Daripada kisah Zulqarnain tersebut, dapatlah kita kaitkan bahawa dalam membangun peradaban Islam itu mempunyai beberapa elemen penting iaitu aqidah, syariat dan akhlak.

\section{Aqidah}

Kepentingan aqidah dalam peradaban Islam sangat jelas, kerana segala bentuk pembangunan yang hendak dibina oleh manusia haruslah bermula dengan diri mereka dahulu, kemudian barulah dilebarkan kepada yang lain-lainnya. Pembina peradaban yang memiliki kesatuan jiwa, berfikir dan bertindak akan membawa wujudnya peradaban yang bertahan lebih lama dan lebih harmoni serta mendapat keberkatan dan rahmat serta keampunan daripada Allah SWT (Nik Mohd).

Kepincangan aqidah bererti musnahlah segala-galanya, kerana aqidah adalah ibarat nadi kepada jasad manusia, asas kepada sebuah binaan atau akar kepada sebatang pokok. Oleh itu rosaknya bererti binasalah badan, binaan dan pokok tersebut.

Dengan kekuatan aqidah, jiwa seorang muslim itu menjadi tabah, berani, sabar, tawakal, reda, yakin, jujur, ikhlas dan sentiasa merendah diri kepada Allah SWT. Mereka akan menyedari bahawa segala sifat keagungan, kemuliaan dan kebesaran adalah milik Allah SWT. Firman Allah SWT: 


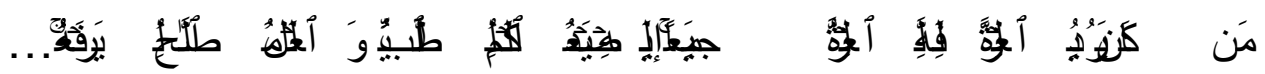

Maksudnya: "Barangsiapa yang menghendaki kemuliaan, maka bagi Allah-lah kemuliaan itu semuanya. Kepada-Nya-lah naik perkataan-perkataan yang baik dan amal yang saleh dinaikkanNya..." [Surah Fatir, 35:10]

\section{Syariat}

Syariat ialah hukum-hakam perundangan dan peraturan yang diturunkan Allah SWT melalui wahyuNya kepada Nabi Muhammad SAW yang bertujuan mengatur kehidupan peribadi, keluarga, masyarakat dan negara, merangkumi permasalahan ibadah, muamalah, kekeluargaan dan jenayah. Dengan syariat manusia dapat mengabdikan diri kepada Allah SWT dan melaksanakan amanah Allah SWT sebagai khalifah Allah SWT di muka bumi (Abd Aziz Harjin).

Selepas aqidah, syariat menjadi elemen kedua yang penting dalam peradaban Islam. Semua aspek yang terkandung dalam ciri-ciri sesebuah peradaban, mestilah berdiri dan tegak atas syariat. Dalam erti kata lain, sesuatu yang menjadi elemen peradaban mestilah bergerak dan berkembang mengikut hukum dan ketentuan Allah SWT dan Rasul-Nya (Nik Mohd Rosdi) Jika tidak di dasari kepada syariat Allah SWT, secara automatiknya ia bukan lagi peradaban Islam.

\section{Akhlak}

Akhlak ertinya perangai, sikap, tingkah laku, budi pekerti yang menjadi kebiasaan bagi seseorang. Jika ia membiasakan diri dengan perangai yang baik maka disebut akhlak baik atau memadai disebut sebagai akhlak.

Kecemerlangan sesebuah peradaban amat dipengaruhi oleh akhlak yang baik. Kebejatan sosial dalam masyarakat adalah disebabkan kedangkalan akhlak di kalangan para anggotanya. Jatuh bangunnya sesebuah bangsa dan peradaban amat bergantung kepada akhlak (Abu Abdullah Ahmad).

Sabda Nabi Muhammad SAW dalam sebuah hadis:

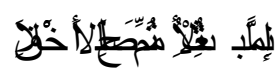

Maksudnya: "Sesungguhnya aku diutus untuk menyempurnakan akhlak yang baik." (HR. Ahmad) (Abu Abdullah Ahmad).

Ketiga-tiga elemen yang disebutkan adalah saling kait mengait antara satu sama lain. Jika diabaikan salah satu daripada unsur akidah atau syariat atau akhlak, maka tidak mungkin lahirnya sesebuah peradaban Islam.

Yusuf al-Qardhawi dalam penulisan beliau telah menggambarkan bahawa peradaban Islam adalah sebuah peradaban yang dapat memberikan ia agama tetapi dia tidak kehilangan ilmu pengetahuan, yang dapat memberi keimanan tetapi tidak melenyapkan akal, yang memberi roh (jiwa) tetapi tidak menghalang material, yang memberi akhirat tetapi tidak menghalang ia dari dunia, yang memberi kebenaran tetapi tidak menghalang ia dari kekuatan, dan memberi akhlak tetapi tidak merampas kebebasan (Yusuf Al-Qardhawi). Maka jelaslah di sini jika membangun sesebuah peradaban menurut al-Qur'an, ia dapat melahirkan sebuah peradaban yang universal bagi seluruh umat manusia di dunia ini.

\section{Kesimpulan}

Sesebuah peradaban itu akan menjadi sempurna jika ia mengikuti segala apa yang telah dimaklumkan di dalam al-Quran. Banyak contoh yang dapat dilihat di dalam al-Quran, bagaimana sesebuah peradaban itu tidak akan kekal lama jika ia tidak meletakkan aqidah, syariat dan akhlak sebagai elemen penting dalam membangun peradaban tersebut. 
Kisah Zulqarnain yang diceritakan dalam surah al-Kahfi, menunjukkan bahawa dengan meletakkan aqidah, syariat dan akhlak sebagai elemen penting dalam pembangunan sesebuah peradaban akan membentuk peribadi muslim yang menjaga hubungannya dengan Allah sebagai Pencipta, manusia dan alam yang berada di sekelilingnya. Kisah ini juga dapat kita jadikan sebagai ibrah dan pelajaran bagi membangun dan membentuk sebuah peradaban yang universal.

\section{Rujukan}

Ab. Latif Muda dan Rosmawati Ali (2014). Ulum Al-Qur'an. Pustaka Salam. Kuala Lumpur.

Abd Aziz Harjin (2000). Akidah Sebagai Landasan Kepada Tamadun Islam. (BIROTEKS Universiti Teknologi MARA. Selangor.

Abd Aziz Harjin. Akidah Sebagai Landasan Kepada Tamadun Islam.

Abd Aziz Harjin. Akidah Sebagai Landasan Kepada Tamadun Islam... Ms 16.

Abdul Hadi Awang (2013). Tafsir Surah Al-Kahfi. Aisyah Humaira Publication. Kuala Lumpur. 2013).

Abdul Hadi Awang. Tafsir Surah Al-Kahfi... Ms 20.

Abdul Hadi Awang. Tafsir Surah Al-Kahfi... Ms 216.

Abdul Hadi Awang. Tafsir Surah Al-Kahfi... Ms 224.

Abdullah Bin Muhammad. (2008). Lubaabut Tafsir Min Ibni Katsir. Ter: M. Abdul Ghoffar dan Abu Ihsan. Tafsir Ibnu Katsir. Pustaka Imam Asy-Syafi'i. Bogor.

Abdullah Bin Muhammad. Lubaabut Tafsir Min Ibni Katsir... Ms 296.

Abu Abdullah Ahmad Bin Muhammad (2001). Musnad Al-Imam Ahmad Bin Hanbal. (Beirut: AlRisalah.

Abul A'la Al-Maududi. Al-Hadharah Al-Islamiyah Ususuha Wa Mabadi'uha. Ter: Halimuddin (1985). Asas Dan Prinsip Peradaban Islam. Pustaka Nasional Pte Ltd. Singapura.

Abul A'la Al-Maududi. Al-Hadharah Al-Islamiyah Ususuha Wa Mabadi'uha.

Al-Qurthubi (2008). Al-Jami' li Ahkaam Al-Qur'an. Ter: Amir Hamzah. Tafsir Al-Qurthubi. Pustaka Azzam. Jakarta.

Ibnu Khaldun (1986). Muqaddimah. Ter: Ahmadie Thoha. Muqaddimah Ibn Khaldun. (Pustaka Firdaus. Jakarta.

M. Abdul Jabar Beg (1985). Perspectives of Civilization. Ter: Suhendra Yusuf dan Dodi Sukmayadi. Perspektif Peradaban. (University of Malaya Press. Kuala Lumpur.

Muhammad Asad (1981). Al-Islam 'Ala Muftaraq al-Thoriq. Ter: M. Hashem. Islam Di Simpang Jalan. Pustaka. Bandung.

Nik Mohd Rosdi Nik Ahmad dan Nik Kamaliah Nik Abdullah (2009). Kenalilah Tamadun (AlHadharah). (Pusat Penerbitan Universiti (UPENA), UiTM. Selangor.

Nik Mohd Rosdi Nik Ahmad dan Nik Kamaliah Nik Abdullah. Kenalilah Tamadun (Al-Hadharah)... Ms 50.

Nik Mohd Rosdi Nik Ahmad dan Nik Kamaliah Nik Abdullah. Kenalilah Tamadun (Al-Hadharah)... Ms 52.

Sayyid Quthb (2003). Fi Zhilalil Qur'an, Beirut: Darul Shorouk.

Uthman Bin Sa'id Al-Dani (2010). Al-Sunan Al-Waridah fi Al-Fitan wa Ghawailiha wa Al-Sa'ati wa Asyratiha. Al-Riyadh: Darul 'Ashimah.

Yusuf Al-Qardhawi (1999). Al-Islam Hadharah Al-Ghad. Ter: Haji Juanda Haji Jaya. Tamadun Islam Alternatif Masa Depan. (Maktabah Al-Qardhawi. Selangor.

Yusuf Al-Qardhawi. Al-Islam Hadharah Al-Ghad.

Yusuf Al-Qardhawi. Al-Islam Hadharah Al-Ghad... Ms 173. 